\title{
MEDICINAL PLANTS AND HERBAL MEDICINES USAGE IN THE SOCIOECONOMIC REALITY OF NORTHEAST BRAZILIAN COCOA REGION
}

\author{
Leonardo G.M. Cardoso*, Rafael S. Silva*, Gesael P. F. Júnior*, Luiz A. M. Cardoso**, \\ Alexandre J. de Oliveira*, Mônica de M. Pires***, Aline O. da Conceição**** \\ Corresponding author: Leonardo Galvão Cardoso - leogmc1989@hotmail.com \\ * Departamento Ciências da Saúde, Universidade Estadual de Santa Cruz, Ilhéus, Bahia \\ ** Departamento de Química e Exatas, Universidade Estadual do Sudoeste da Bahia, Jequié, Bahia \\ *** Departamento de Ciências Econômicas, Universidade Estadual de Santa Cruz, Ilhéus, Bahia \\ **** Departamento de Ciências Biológicas, Campus Soane Nazaré de Andrade, Ilhéus, Bahia
}

\begin{abstract}
Objective: This work describes the medicinal plants and/or herbal medicines usage by the population assisted by Brazilian Public Health System (SUS), and their prescription by health professionals in the Brazilian Northeast. Methods: Questionnaires were applied for public health system users; pharmacists who work at compounding pharmacies; physicians and nurses. Data were submitted to descriptive statistical analysis. Results: The sociodemographic profile was individuals between 40 and 59 yearsold, majority of females, low family income, and low schooling levels. A great number of individuals $(89.3 \%)$ used plant products, without prescription and based on traditional knowledge. There was a common trend regarding a lack of knowledge of plant toxicity potential. Regarding health professionals, $90 \%$ stated having knowledge about medicinal plants and/or herbal medicines, and $80 \%$ believe that its effect is important. Conclusion: The study reveals the major usage of herbal medicines and/or medicinal plants by familiar low income and low schooling level without prescription from a physician. These factors may cause a risk/benefit imbalance where could have a reduction in therapy efficacy and high toxicity potential of the drugs. This reinforces the need of pharmacosurveillance toward usage of medicinal plants and herbal medicines in the public health system.
\end{abstract}

Keywords: Medicinal plants; Herbal medicines; Public health system. 


\section{INTRODUCTION}

Modern mankind stands apart from that of other eras for its high consumption of medicines. (1) That is especially due to the technological development arrived at by 2oth century pharmaceutical industries, which discovered and sold drugs for cardiovascular, central nervous system and antiinfective treatments, among others. ${ }^{(1,2)}$ However, in spite of the large quantity of allopathic medicines on offer, their availability is still far from reaching a large part of the world's population due to high costs and little access to medical prescriptions. ${ }^{(3,4)}$ For this audience, the main forms of treatment are the so-called alternative therapies $(5,6,7)$ which has important role as a way to expand the possibilities of care by health professionals. ${ }^{(8,9)}$

Two types of plant products used in alternative medicine can be highlighted and are the focus of this study: medicinal plants and herbal medicines. Medicinal plants are those traditionally used by a population or community and are capable of preventing, relieving or curing diseases. Herbal medicines are the end products of technology transformation operations (division, classification, extraction, purification, concentration, and drying) performed on plant materials to obtain medicinal drugs, and are regulated by government norms. ${ }^{(10)}$

Population focus of the study is assisted by the public health of the two largest cities of the cocoa micro-region, Ilhéus and Itabuna, which are centers of referral and counter-referral health, covering both residents of the two cities, as neighboring municipalities. Cocoa micro-region is located in the southern meso-region of Bahia, Brazil (Figure 1), between the meridian $39^{\circ} 00^{\prime}-39^{\circ} 40^{\prime}$ and parallel $14^{\circ} 20^{\prime}-15^{\circ} 10^{\prime}$ with climatic conditions favorable to cocoa production. The socioeconomic reality targeted here represents the repercussion of high economic development in 80's followed by economic crises due to cocoa illness resulting in serious repercussions to cocoa production and availability of products and services in the region. $(11,12,13)$

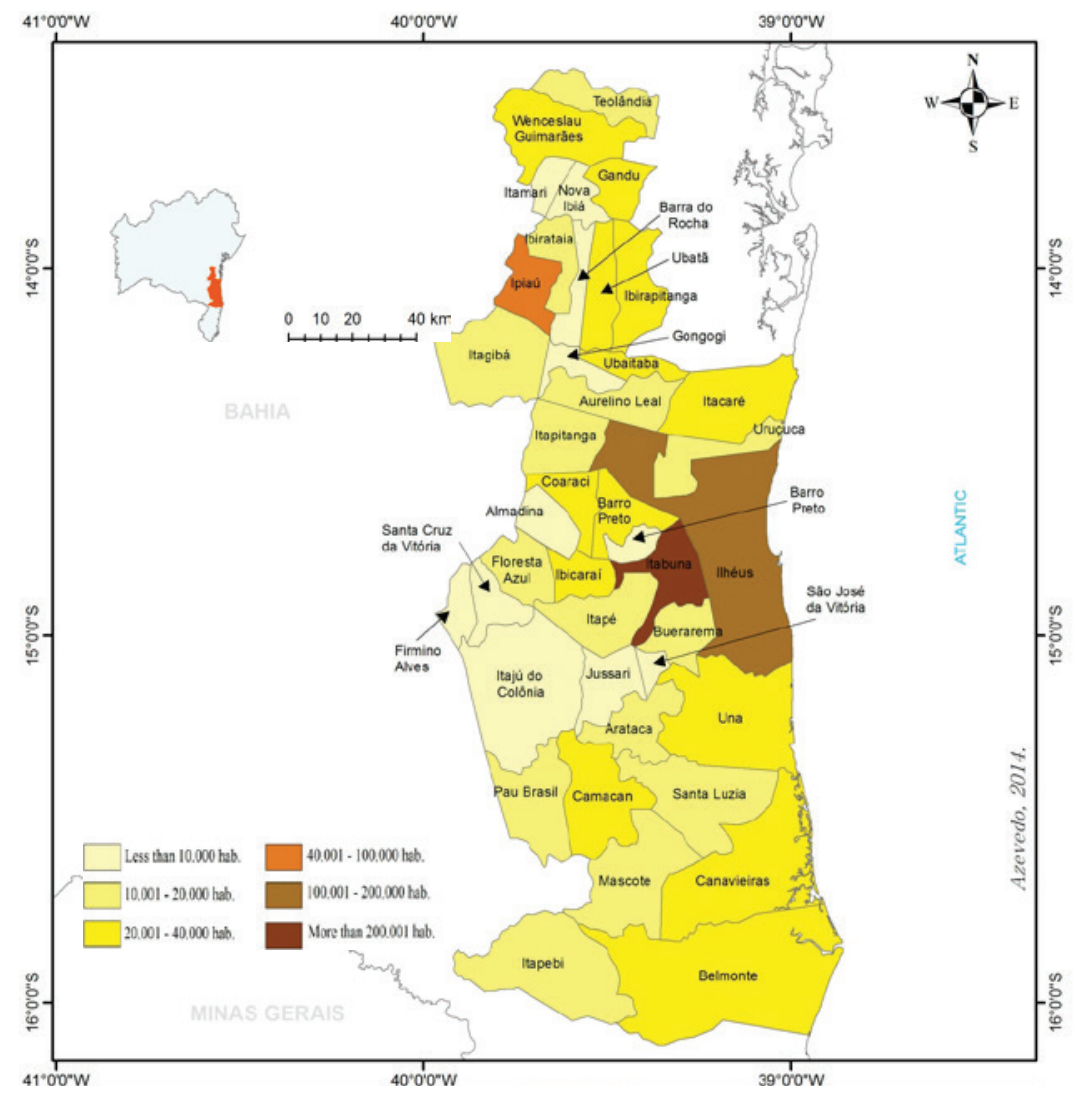

Figure 1 - Ilheus-Itabuna micro-region (red square), located in the southern meso-region of Bahia, Brazil(14) 
The actual panorama of Ilheus and Itabuna reveals that these two main cities have strong economic influence over surrounding cities in the area. According to 2010 National Household Sample Survey (PNAD), conducted by the Brazilian Statistic Bureau (IBGE), the population of Ilheus and Itabuna was about 184.236 (104.67 inhabitants/ $\mathrm{km} 2$ ) and 204.667 (473.50 inhabitants/km2), with an estimated population for 2013 of 184.616 and 218.124, respectively. ${ }^{(15,16)}$

The present work proposed to come into contact with primary health care reality in order to diagnose the use of medicinal plants and/or herbal medicines by the population of south Bahia's cocoa region, and their recommendation/prescription by health professionals who work at same location. A few aspects of the region's sociodemographic reality (family income, age, schooling and gender) were analyzed as an important research point, together with the management and knowledge of the toxic potential of these resources.

\section{MATERIAL AND METHODS}

This study was approved by the Human Research Ethics Committee, protocol \# 435/2011. It consisted of a qualitative-quantitative analysis. The research was conducted from September 2011 to February 2013 in the 7 public primary assistance health units and compounding pharmacies, which are pharmacies that customize medication solutions for patients whose healthcare needs cannot be met by manufactured medications, located in Ilheus and Itabuna, Bahia, Brazil.

Questionnaires ( $n=259)$ aimed at three categories of interviewed subjects: 1 ) users of health care units ( $\mathrm{n}=245$ ) - Basic Health Units (BHU/Unidade básica de sáude, UBS), Family Health Units (FHS/Unidade de saúde da família, USF) and one Medium and High Complexity Unit in Itabuna and Ilheus; 2) physicians and nurses of the Ilheus and Itabuna Health Units (UBS, USF) $(n=10) ; 3)$ supervising pharmacists and/or owners of compounding pharmacies in both municipal areas $(n=4)$.
The subjects consisted of individuals aged 18 or more, of both gender, any degree of schooling and profession, and whose spoken language is Portuguese. The questionnaires were answered while the subjects were waiting to be seen by the Health Unit physician. The choice of units was based on the possibility of easy access to conduct the research and on an existing agreement with the University. The queries applied to the health professionals aimed at understanding the production, commercialization and prescription of compounded herbal medicines, which are known to come from plant extracts and substances alike.

For the first category, users of public health system, apart from the questionnaire on knowledge of medicinal plant use, it was used a form with general data such as: family income, schooling, gender, and age. In relation to medicinal plants usage by these subjects, questions were about: knowledge of medicinal plants and/or herbal medicines; frequency of use; places where these resources are usually bought; use quality (whether informal or prescribed); knowledge of possible side effects; belief in the efficacy of medicinal plant products; and their opinion about the cost of obtaining these medicines.

The second database, which included the physicians and nurses $(n=10)$ in the staff of the selected Health Units, aimed at comprehending how the medicinal plants and herbal medicines are being prescribed by health professionals.

The third category included pharmacists working at commercial establishments known as "compounding pharmacies" $(n=4)$, who were interviewed at their place of work by prior appointment. The interview with these professionals aimed at understanding the process of producing and buying compounded medicines, which are known to come from plant extracts and substances alike, frequency of usage and the accessibility by the population.

For this study, convenient non-probability sampling technique was used. Data were tabulated and submitted to descriptive statistics in order to identify correlation between socioeconomic variables and health. 


\section{RESULTS AND DISCUSSION}

\section{SOCIODEMOGRAPHIC DESCRIPTION OF POPULATION}

From all users interviewed in health units, 196 were female (81\%) and 46 male (19\%), having a preponderance of women in Ilheus $(n=50 ; 74,62 \%)$ in relation to men $(n=17 ; 25,37 \%)$ as well as Itabuna, with $83,42 \%(n=146)$ of women and $16,57 \%(n=29)$ of men, meaning that in health care decision there is a gender issue involved. Most of the individuals are included in the 40 to 59 age group ( $n=30 ; 44.77 \%$ in Ilheus and $n=85 ; 48.57 \%$, in Itabuna), demonstrating the relation between the presence of higher number of women and the demand for health services by this population segment due to chronic diseases, beginning of the menopause and the senescence process characteristic of the predominant age. Individuals aged over 60 represented the lowest portion of the interviewed population $(n=6 ; 8.95 \%$, in Ilheus and $n=12 ; 6.85 \%$, in Itabuna), because for this population there is specific public health programs, in addition to location and time of data collection which did not coincide with the offer of services to the elderly.

With regard to the family income, it was observed that around $51 \%$ of interviewed $(n=37)$ from Ilheus have a family income of up to 1 minimum wage, $45 \%(n=30)$ have up to 10 minimum wages (Figure 2) and the rest of them (4\%) did not answered the question. In relation to Itabuna, 88 participants $(50.28 \%)$ stated monthly income of up to 1 minimum wage, while 78 (44.57\%) have between 1 to 10 minimum wage. Thus, it is observed that most of the population assisted at public clinics in IlheusItabuna-axis have low wage income, and confirms the need of the public health service.

With regard to schooling level, it was observed the predominance of people with incomplete secondary education, approximately $63 \%(n=43)$ and $54 \%(n=95)$ in Ilheus and Itabuna, respectively. Few are those who have a university or postgraduate degree, corresponding to 19 respondents (7.8\%), with 3 individuals in Ilheus and 16 in Itabuna. The rest of the interviewees reported having complete secondary school. Of the total respondents in Ilheus, two did not declare schooling. Thus, there is evidence of a difference between the two cities in relation to educational condition; however, a low level of education is more prevalent in those public health system units. It appears that the low level of education can be considered a risk factor to health due to lack of adequate information, unsystematic usage and toxic effects by inappropriate use of the substances. ${ }^{(17)}$

\section{MEDICINAL PLANTS AND/OR HERBAL MEDICINES KNOWLEDGE AND UTILIZATION BY HEALTH CARE UNIT USERS}

Issues were evaluated in the study about the use of medicinal plants and/or herbal medicines by public health service users in both municipal areas. With the analysis, it was observed that: $89.3 \%(n=218)$ knew medicinal plants; $10.6 \%(n=26)$ declared no knowledge of herbal medicines, and only one did not answered the question. Through statistical analysis of the questionnaires, the plant based products (medicinal plants or herbal medicines) are used by most of the interviewed ( $n=207 ; 84.49 \%$ ), however only $8.57 \%(n=21)$ have access through prescription. The rest of them (91.43\%) use plant products by self-medication. This situation is confirmed by the statement of $63.67 \%$ of the total of interviewed $(n=156)$ which declared to get their products at their backyards or from others backyards. The majority of interviewed stated believe that medicinal plants have curative effect (82.04\%; $n=201$ ), do not have side effects $(88.98 \% ; n=218)$, and are cheaper to buy when compared to conventional synthetic drugs (78\%; $n=46$ for Ilheus and $88 \% ; n=152$ for Itabuna). It is observed that there is an association between the use of medicinal plants and/or herbal medicines with the level of income, reflecting the low purchasing power of the population residing in 
the analyzed region (Figure 2). It was noted there is a strong association between the use of medicinal plants and the low buying power of the population living in this region, which is characterized by an uncontrolled growth model with growing unplanned urbanization and high poverty levels. ${ }^{(12)}$

The most common name of plants, used as alternatives to conventional therapy, reported were: Lemon Balm ( $n=146)$; Boldo $(n=100)$; Lemon Grass $(n=79)$; Anise $(n=52)$; "Mastruz" [Chenopodium ambrosioides] $(n=42)$; Spearmint $(n=38)$; Broadleaf Plantain $(n=30)$. When asked about the purpose of their use, the main clinical conditions reported were: treatment of anxiety disorders and insomnia; treatment of dyspepsia and/or gastritis; treatment of headaches; alleviation of inflammatory signals or symptoms; treatment of Diabetes Mellitus.

\section{MEDICINAL PLANTS AND/OR HERBAL MEDICINES PRESCRIPTION BY HEALTH PROFESSIONALS}

The questionnaires handed to physicians and nurses attempted to understand the scale of prescribing herbal medicines and/or medicinal plants for the treatment of organic conditions. Of the total number of individuals interviewed $(n=10)$ : only one declared not knowing medicinal plants and/ or herbal medicines; the rest of them ( $n=9 ; 90 \%)$ claimed to know and use these resources, reporting that they have already prescribed herbal medicines and medicinal plants to their patients $(n=6 ; 60 \%)$ and consider them to be important resources from a therapeutic point of view $(n=8 ; 80 \%)$. The frequency of prescription by these professionals is reasonable, since $40 \%(n=4)$ have never prescribed or indicated them (Figure 3 ). When they used this form of therapy, the main health conditions aimed reported were: skin diseases; gastrointestinal pathologies; psychic and neurological illness; liver diseases; heart diseases; and gynecological ailments. Some of reported herbal medicines were: Ginkgo biloba L., Valeriana officinalis L., Hypericum perforatum L., Panax ginseng C.A. Mey, Digitalis purpurea L., Passiflora edulis Sims and Hedera helix Linn.
The professionals from compounding pharmacies were interviewed in relation to the knowledge of herbal medicines and medicinal plants, frequency of plant extract-based formulations, and use/ commercialization. The results demonstrated that: all the professionals had some knowledge of medicinal plants and/or herbal medicines and their use; all claimed to prepare formulations with plant extracts and related substances in their establishments; and all the interviewed individuals said the patients adhere well to the treatment with formulas containing medicinal plants extracts. Only one stated that the acceptance is low by users because the majority of physicians do not believe in the efficacy of this kind of treatment. Asked about the possibility of side effects by using these substances, they affirmed there were practically no side effects from using the formulas, according to their experience, with exception of one pharmacist that mentioned that "high doses of Sene (Cassia angustifólia) predisposes to abdominal pain". However, all of them recognize that the use of herbal medicines without supervision represents a real risk for occurrence of side effects. For these professionals, the accessibility of these therapeutic resources is due to low cost of formulas in relation to conventional medicines and acceptability when prescribed by physicians. Only one said that access is restricted because most physicians do not believe in the efficacy of the formulas. Among the main medicinal plant products or plant products reported to be used in formulas were: Citrus medica L.; Valeriana officinalis L.; Passiflora incarnata; Aloe vera (L.) Burm. F.; Faseolamina; Guarana (Paulínia cupana H. B. Q K); Horse Chestnut (Aesculus hippocastanum L.); Ginkgo biloba L. and Isoflavones.

Therefore, taking in consideration the promising expansion of the natural products market in Brazil and their growing acceptance by professionals and the public, it is crucial the improvement of public policies to achieve incisive information and awareness on the judicious use of so-called natural products together with the recognition and a great incentive to train professionals in Complementary and Integrative Practices (PICs) recognized by the authors in the area. ${ }^{(1,8,18)}$ 


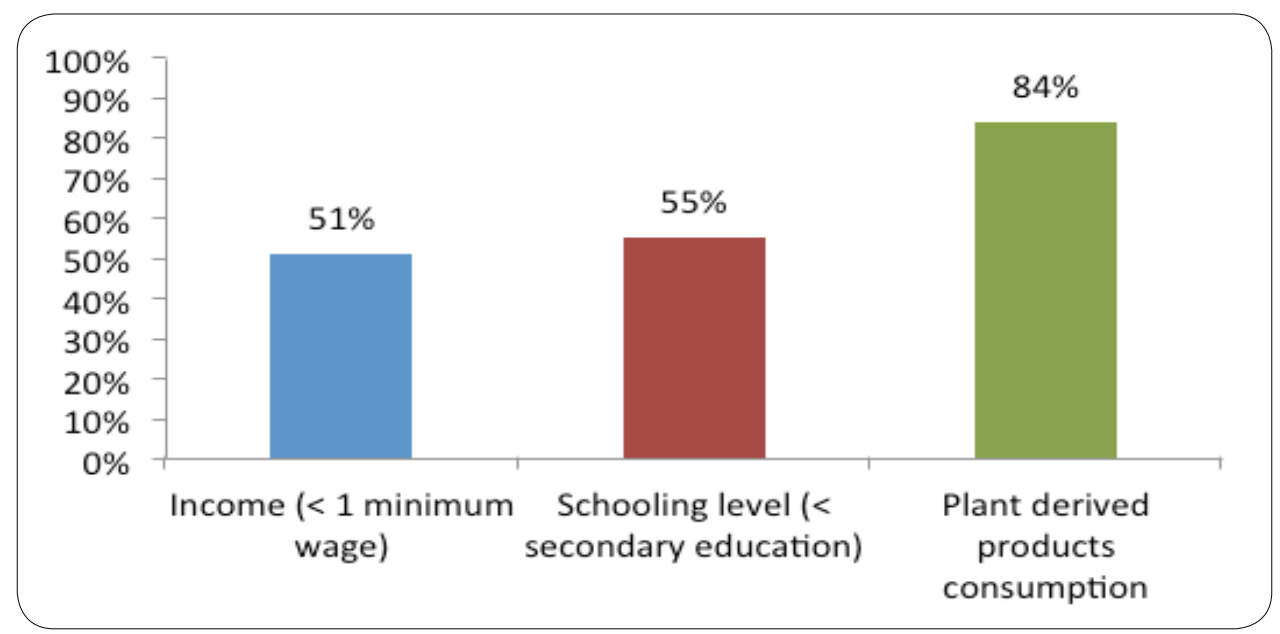

Figure 2 - Socioeconomic profile of total respondents in the public health system of Itabuna and Ilheus, Bahia, and the consumption of medicinal plants and/or herbal medicines

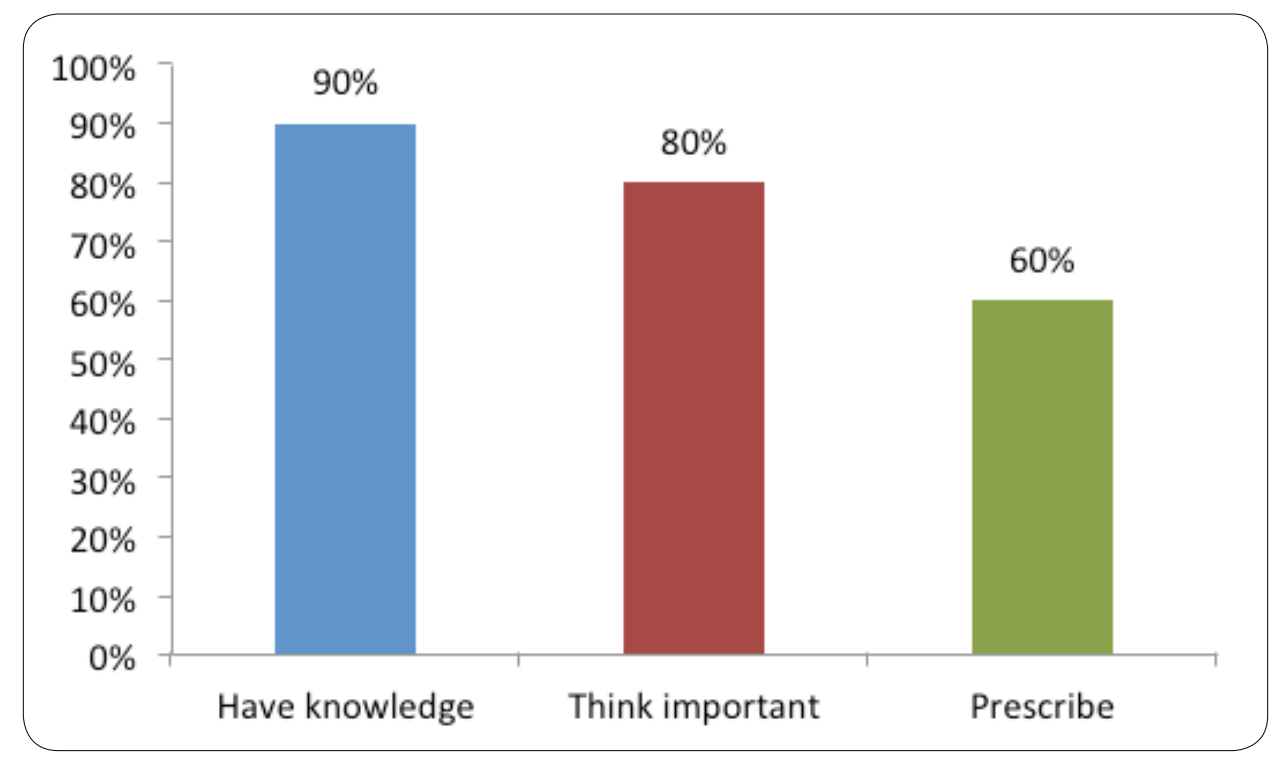

Figure 3 - Knowledge, level of importance and prescription of medicinal plants and,or herbal medicines by professionals in the public health system in Itabuna and Ilheus, Bahia

\section{CONCLUSION}

According to the survey, it is observed that the indication and/or prescription of herbal and other natural products based on plant extracts by health professionals is common, although the largest use of this resource is under non-prescribed form, especially among low-income and low-education level population, which is the largest number of users in the public health system. It also can be inferred that the use of alternative strategies to conventional synthetic drugs is a common reality, especially in the population using the public health system.

Despite the demand for manipulated formulas in compounding pharmacies under physician prescription, the use of medicinal plants and herbal medicines without supervision is an evident situation in the southern region of Bahia. 
These factors can generate a benefit/risk ratio which reduces the degree of efficiency and raises the potential toxicity of the product. Furthermore, despite the growing search for integrative therapies strategies, studies about herbal medicine are still limited in Brazil, being necessary more researches in this area to enrich the knowledge of professionals and students in health care practice and to support pharmacosurveillance in the public health system.

\section{AUTHOR CONTRIBUTION}

The authors Leonardo G. M. Cardoso and Rafael de Santa Silva contributed in the drafting process, as well as defining the goals of the study; they participated in the interviews, applying the questionnaires in the Health Units; organizing and tabulating the data, making graphs and charts, and writing the article. The author Aline Oliveira da Conceição collaborated in the definition of the research and the study design, conducting the research, organizing the activities, writing the proposal and the scientific writing. The author Mônica de Moura Pires collaborated in the stage of analysis and description of socioeconomic data and writing the last version of the article. Gesael P. F. Junior contributed in the application of questionnaires and critical reading of the proposed work. Luiz A. M. Cardoso assisted in project design and scientific writing. Alexander J. Oliveira contributed in the questionnaires and critical reading of the proposed work. All authors read this version of the manuscript and agree with this submission to the Brazilian Journal of Medicine and Human Health (BJMHH).

\section{ACKNOWLEDGMENT}

The authors like to thank students from the State University of Santa Cruz (UESC), Ilheus, Bahia that collaborated with this study, UESC and County Health Department of Ilheus and Itabuna. This study was financial supported by Fundação de Amparo à Pesquisa do Estado da Bahia (FAPESB) and UESC.

\section{REFERENCES}

1. Veiga Junior VF. Estudo do consumo de plantas medicinais na Região Centro-Norte do Estado do Rio de Janeiro: aceitação pelos profissionais de saúde e modo de uso pela população. Rev bras farmacogn. 2008;18(2):308-313.

2. Niero R. Fármacos, fitofármacos e fitoterápicos: abordagem econômica e de mercado. In: Bresolin TMB, Cechinel Filho V, organizadores. Fármacos e medicamentos: uma abordagem multidisciplinar. São Paulo: Santos, 2010. p. 1-15.

3. Akerele O. Summary of WHO guidelines for assessment of herbal medicines. HerbalGram. 1993;28: 13-19.

4. Costa AA. O uso de medicamentos pelas famílias atendidas no Centro de Saúde 8 do Gama - DF. Com ciências saúde 2007:18:117-127.

5. Ritter MR, Sobierajski GR, Schenkel EP, Mentz LA. Plantas usadas como medicinais no município de lpê, RS, Brasil. Rev bras farmacogn. 2002;12:51-62.

6. Pereira RC, Oliveira MTR, Lemos GCS. Plantas utilizadas como medicinais no município de Campos de Goytacazes - RJ. Rev bras farmacogn. 2004;14 (Supl. 1):37-40.

7. Vendruscolo GS, Rates SMK, Mentz LA. Dados químicos e farmacológicos sobre as plantas utilizadas como medicinais pela comunidade do bairro Ponta Grossa, Porto Alegre, Rio Grande do Sul. Rev bras farmacogn 2005;15(4):361-372.

8. Azevedo E, Pelicioni MCF. Práticas integrativas e complementares de desafios para a educação. Trab educ saúde. 2011;9(3): 361-378.

9. Tesser CD, Sousa IMC. Primary Care, Psychosocial Care and Complementary and Alternative Medicine: elective affinities. Saude soc. 2012;21(2): 336-350.

10. Sonaglio D, Ortega GG, Petrovick PR, Bassani $\mathrm{VL}$. Desenvolvimento tecnológico e produção de fitoterápicos. In: Simões CMO, Schenkel EP, Gosmann G, Mello JCP, Mentz LA, Petrovick PR. Farmacognosia, da planta ao medicamento. Porto Alegre: EDUFRGS; Florianópolis: EDUFSC; 1999. p. 221-258.

11. Faria Filho AF, Araujo QR. Zoneamento do meio físico do município de llhéus, Bahia, Brasil, 
utilizando a técnica de geoprocessamento. Ilhéus: CEPLAC/CEPEC; 2OO3. (Boletim Técnico, n. 187)

12. Silva AFR, Trevizan SDP, Mascarenhas, GCC. Consensualismo, constrangimento e a sustentabilidade das associações de produtores rurais de llhéus, Bahia, Brasil. 2O12. [citado maio 2012]. Disponível em: www.uesc.br/cursos/pos graduacao/mestrado/.../antoniofernando.rtf.

13. Sena NAMO, Pereira Filho CA. Análise da eficiência técnica dos municípios da microrregião itabuna-ilhéus, estado da bahia usando a abordagem DEA (Data Envelopment Analysis). [citado Feb 2014] Available from: http://www.sober.org.br/palestra/12/O5O286. pdf.

14. Azevedo A. Microrregião llhéus-Itabuna: população absoluta 2010. 2014. [citado July 2014] Available from: https://comunicidades. files.wordpress.com/2014/O7/populacao_ mircoilheus-itabuna.png
15. IBGE. Cidades. Bahia-Ilhéus. 2004b. [citado March 2014] Available from: http://cidades.ibge. gov.br/xtras/perfil.php?lang=\&codmun=291360 \&search=bahia|ilheus(2004a); Itabuna: http:// cidades.ibge.gov.br/xtras/perfil.php?lang=\&cod mun=291480\&search=bahia||tabuna

16. Programa das Nações Unidas para o Desenvolvimento - PNUD, Instituto de Pesquisa Econômica Aplicada - IPEA, Fundação João Pinheiro - FJP. Atlas do Desenvolvimento Humano no Brasil 2013. [citado March 2014]. Available from: http://atlasbrasil.org.br/2O13/ perfil_print/ilheus_ba; Perfil do município de Itabuna, BA http://atlasbrasil.org.br/2O13/perfil_ print/itabuna_ba

17. Veiga Junior VF, Pinto AC, Maciel MAM. Plantas Medicinais: cura segura? Química Nova, 2005;28(3):519-528.

18. Santos RL, Guimaraes GP, Nobre MSC, Portela AS. Análise sobre a fitoterapia como prática integrativa no Sistema Único de Saúde. Rev bras plantas med. 2011;13(4):486-491. 